\title{
Laser microdissection and cryogenic nuclear magnetic resonance spectroscopy: an alliance for cell type-specific metabolite profiling
}

\author{
D. Hölscher · B. Schneider
}

Published online: 14 November 2006

(C) Springer-Verlag 2006

\section{Erratum to: Planta}

\section{DOI 10.1007/s00425-006-0404-z}

Unfortunately, due to a mistake in the journal production department, the sequence of authors and the address were published with errors. The complete address is given here:

D. Hölscher · B. Schneider ( $\square)$

Max-Planck-Institut für Chemische Ökologie,

Beutenberg Campus, Hans-Knöll-Str. 8,

07745 Jena, Germany

e-mail: schneider@ice.mpg.de

The online version of the original article can be found at http://dx.doi.org/10.1007/s00425-006-0404-z.

D. Hölscher · B. Schneider $(\bowtie)$

Max-Planck-Institut für Chemische Ökologie,

Beutenberg Campus, Hans-Knöll-Str. 8,

07745 Jena, Germany

e-mail: schneider@ice.mpg.de 